\title{
MACHINABILITY IMPROVEMENT OF POWDER METALLURGY STEELS
}

\author{
Miklós Czampa, Balázs Zsolt Farkas, Tibor Szalay
}

Original scientific paper Powder metallurgy is one of the possible competitive options among those up-to-date replication technologies that are able to produce final shapes with no need for subsequent machining. However, there are some special geometries which require the subsequent machining of certain parts produced by powder metallurgy. These include grooves, threads and cross bores. The goal of the research discussed in this paper is to determine the effect of the material composition changes on the secondary machining properties of powder metallurgy steels (PMS). Varying the carbon and the copper content of the powder mix cutting force measurement was carried out during face grooving tests in turning. Using the ranking number of the measured characters, the machinability of samples was evaluated with each powder mixes. The optimal percentages of the copper and the carbon content were determined based on the results of the experimental measurements.

Keywords: cutting force measurements; grooving test; machinability evaluation; material composition changes; metallic matrix composites; powder metallurgy

\section{Poboljšanje strojne obradivosti čelika metalurgije praha}

Izvorni znanstveni članak Metalurgija praha je jedna od mogućih opcija među postojećim tehnologijama kojima se mogu proizvesti završni oblici bez dodatne obrade. Međutim, postoje neke posebne geometrije koje zahtijevaju dodatnu obradu nekih dijelova proizvedenih metalurgijom praha. To su žljebovi, navoji i poprečni provrti. Cilj je ovog istraživanja utvrditi učinak promjena sastava materijala na sekundarna svojstva obradbe čelika metalurgije praha - powder metallurgy steels (PMS). Variranjem sadržaja ugljika i bakra mješavine praha provedeno je mjerenje sile rezanja tijekom ispitivanja glodanja utora kod tokarenja. Primjenom rangirnog broja izmjerenih veličina, procjenjivana je obradivost uzoraka svake mješavine praha. Određeni su optimalni udjeli bakra i ugljika na temelju rezultata dobivenih eksperimentalnim mjerenjem.

Ključne riječi: ispitivanje glodanja; kompoziti s metalnom matricom; metalurgija praha; mjerenje sile rezanja; procjena obradivosti; promjene sastava materijala

\section{Introduction}

Nowadays, there is a growing need for replication technologies which are capable of directly and immediately producing the full shape and final size of parts. Powder metallurgy is one of the suitable options for this manufacturing demand. Powder metallurgy components can be found in several application areas such as bushings, self-lubricant parts, gears, etc. in the automotive and machine tool industries.

Generally, these parts are formed to final shape, and they do not need subsequent machining operations. Nevertheless, threads, cross holes or slots cannot be produced economically through directly using the compacting and sintering processes of powder metallurgy. In these cases it is more economical to generate these features using secondary machining operation(s) (e.g. turning, milling, and drilling). Because offering a solution to secondary cutting operations is not the most important task in powder metallurgy industry, this field uses materials with the help of which optimal physical properties of the sintered parts can be achieved. Therefore, the machinability of these materials plays only a secondary role. However, recently, an increasing number of researchers have investigated the machinability of sintered materials.

\subsection{Literature review}

The machining of porous materials using traditional cutting operations results in different behaviours in the machining process. In contrast to the metals produced by conventional alloying methods, the properties of powder metallurgy parts depend on the composition of the powder mixture, the compacting pressure, and the sintering conditions applied [1, 2]. In fact, the international literature abounds in investigations, experimental results and data about the machining of steels produced in conventional metallurgy methods. There are lots of researches where the machinability of different alloys is studied; however, in most cases these studies are limited to the measurement of cutting force and tool wear.

The machinability of tool steels in turning operations was investigated in [3]. During the test, the effects of tool material, the type of coating on the insert and the cutting parameters that affect machinability were taken into consideration. According to the results the amount of flank wear and cutting forces were appropriate parameters to determine tool life, and it was observed that flank wear is a more reliable parameter for determining remaining tool life than crater wear.

The effects of the used cutting parameters have great impact on the emerging cutting forces, tool wear and surface integrity during machining difficult-to cut materials $[4,5$, and 6]. The results of these investigations showed that the cutting speed is the critical parameter that influences the machining process. With optimal cutting speed values both relatively low cutting forces and improved surface qualities can be obtained. This consideration is important, because it confirms that using optimal cutting speeds can be an option to improve both the productivity and quality of the production of difficult to cut materials.

Turning and drilling tests were made in order to compare the machinability of austenitic stainless steel powder metallurgy materials with different material compositions and materials with high sintered density by $[7,8]$. The author found that additive elements have better 
effects on the secondary machining properties and it is possible to produce sintered parts at lower costs with good machining properties.

The effect of carbon addition on the formability properties of sintered metals was investigated by [9]. The test results showed that as the carbon content became higher the pore size was smaller, and as the pore size became smaller the formability stress value increased.

The workability behaviour of ferrous powder metallurgy materials with different molybdenum content was investigated by $[10,11]$. They found that steel with $1,5 \%$ molybdenum had better machinability properties compared to other steels and good surface quality and satisfactory tool life can be achieved in dry conditions at relatively high cutting speeds using commercial tools.

A review about the machining of Aluminium matrix composite materials including the existing and ongoing developments in these fields of science was made by [12] Tool life, tool wear, machinability and understanding chip formation mechanism have been highlighted in that article. These materials are really important and widely used nowadays in the automotive industry [13].

Nowadays, industrial companies try to offer powder grades developed especially for secondary machining purposes. These powder mixtures contain different additive elements that can help during the material removing process by cutting operations. Longitudinal turning tests were carried out in order to investigate the effects on the machinability of different additives in the case of pre-alloyed PMS by [14]. It was found that new machinability enhancers had no detrimental effects on the mechanical properties of the material system, and that it provided good tool protection, corrosion resistance and significant improvement on machinability compared to $\mathrm{MnS}$.

The machinability of newly developed stainless PMS grades using turning and drilling operations was investigated by [15]. The results showed that tool life can be extended through the use of the new grades of stainless PMS even at fast cutting speeds but also that these materials offer better productivity and longer tool life compared to standard grades of stainless PMS. It was also discovered that adhesive tool wear was the major cause of tool failure because stainless steels have soft and gummy matrixes.

\subsection{Hypothetic considerations, and methods}

Machinability is not a general definition. When we speak about the machinability of a chosen material, we are mainly talking about how easy to form, how easy to machine it with the cutting tool. Machinability is an integrated property, which is determined by many factors. Up to now there is not a single parameter or a test method which specifically describes it.

Normally, the machinability can be expressed by empirical way, with mechanical parameters of the machined material like hardness and tensile-strength values, it can be expressed by absolute and relative metrics, or we can create different indexes. During our investigations we focused on the cutting behaviour of the different MMC compositions, as an aspect of the machinability. Contrary to machining the test specimens in its Green-state, those were machined in their final mechanical condition (after sintering), in order to get more realistic results.

The secondary machining properties of the MMC materials can be improved by different ways. Mainly adding different additives like $\mathrm{MnS}$ or $\mathrm{MnX}$ to the base powder mixtures are applied in order to improve the cutting behaviour of the sintered parts.

We presumed in our research that it is possible to improve the secondary machining features by modifying the original material compositions with the regular alloying elements like carbon and copper and it is possible to reach optimal powder compositions where both the mechanical and the secondary machining properties are suitable. In the experimental examination the influence of the alloying elements has been investigated in order to determine their effects on the cutting behaviour.

For investigating the above mentioned parameters, a newly developed test method was used, that we called "grooving test". This test was developed specifically for evaluating the cutting behaviour of MMCs in terms of energy indicators. Our new test can be executed relatively fast, and from the registered cutting force components we could draw the conclusions.

\section{Experimental investigations}

The majority of the parts produced by powder metallurgy are usually rotary parts, or the subsequent machining operations associated with this, e.g. undercuts, threads. Thus, we limited our machining tests to simple turning operations.

The investigation we introduce in this paper focused on only one aspect of the machinability. The energy indicators of the cutting process were analysed to evaluate the machinability of the chosen material compositions. The experiments were carried out using turning operation. To measure the energetic parameters of the material removal simple equipment was used, so the evaluation environment and method can be performed on both NC controlled and conventional lathes. To determine the energetic relations of cutting different MMCs, it is enough to measure parameters which are closely related to the material removal that were in our case the cutting force components.

During the tests, we made a "groove" with defined geometry and depth on the front face of the test specimens. During grooving operations, the cutting speed deviation is negligible along the cutting edge. For this reason, the effect of velocity need not be taken into account. That was the reason why we did not use longitudinal turning operations.

For the test we defined a tool wear limit, this was 0,2 $\mathrm{mm}$ flank wear of the inserts. After each machining operation, we measured the flank wear of the cutting edge with a digital microscope. When this limit was reached, we replaced the worn cutting edge with a new one in order to avoid any impact caused by a worn cutting edge.

Dry machining processes were carried out only because of the harmful properties of cooling-lubricant fluids. This is a commonly used technology to machine porous materials besides using a minimum quantity of 
lubrication. With dry machining, the corrosion of the machined part can be avoided, but it is important to note that in this case tool life is shorter, and cutting forces are greater.

We investigated three main industrially used iron powder mixture groups. Our aim was to establish sintered parts with better secondary machining properties while the original mechanical properties did not deteriorate. Beside these three material groups we investigated a special powder mixture, which was originally developed for secondary machining techniques. The basic powder mixtures and the additional alloying elements were the following:

- The first group consisted of a "pure iron" powder mixture: the so-called NC100.24. This powder mixture contains sponge iron powder particles mixed with a small amount of carbon and copper. Several structural parts can be produced of this mixture due to the good compressibility of this material. In this case, the carbon and copper content varied. The carbon content was modified by adding graphite to the basic powder mixture.

- In the second group, a stainless iron powder mixture called 410L was investigated. Parts made from stainless iron powders also can be found in several places in the industry where the stainless property is a special requirement. In this case, the task was to improve the hardness of this material by varying the copper content of the basic powder mixture. We wanted to examine whether the copper addition has the same effect on the mechanical and machinability properties as in the case of the pure iron powder mixtures.

- The third group consisted of a relatively highly alloyed powder mixture called Distaloy AE. With the increase of alloy content, hardening ability and strength also increase. This powder mixture was developed originally for secondary machining purposes. In this case $\mathrm{MnS}$ was added to the basic mixture in order to improve the secondary machinability properties of the material. We would also like to investigate how much better this powder mixture is to machine than the other powder groups in terms of energy indicators.

The mechanical properties and original material compositions of the investigated powder mixtures can be seen in Tab. 1, and the modifications of the original material compositions can be seen in Tab. 2 .

Table 1 The properties of the original powder mixtures

\begin{tabular}{|c|c|c|c|c|c|c|c|}
\hline Powder Grade & $\begin{array}{c}\text { Apparent density } \\
\mathrm{g} / \mathrm{cm}^{3}\end{array}$ & $\begin{array}{c}\text { Flow } \\
\mathrm{s} / 50 \mathrm{~g}\end{array}$ & $\begin{array}{c}\mathrm{C} \\
\%\end{array}$ & $\begin{array}{c}\mathrm{Cu} \\
\%\end{array}$ & Other & $\begin{array}{c}\text { Green density } \\
\mathrm{g} / \mathrm{cm}^{3}\end{array}$ & $\begin{array}{c}\text { Green strength } \\
\mathrm{MPa}\end{array}$ \\
\hline $\mathrm{NC} 100.24$ & 2,44 & 30 & $0,4 \div 1,5$ & $1 \div 5$ & $\mathrm{Fe}$ & 7,02 & 47 \\
\hline 410L & 2,90 & 32 & 0,02 & 0 & $12,4 \% \mathrm{Cr}, 0,8 \% \mathrm{Ni}, \mathrm{Fe}$ & 6,54 & 13 \\
\hline Distaloy AE & 2,82 & 28 & 0,5 & 1,5 & $\begin{array}{c}1,75 \% \mathrm{Ni}, \\
0,5 \% \mathrm{Mo}, \mathrm{Fe}\end{array}$ & 7,11 & 39 \\
\hline
\end{tabular}

Table 2 The modifications of the original material compositions

\begin{tabular}{|c|c|c|}
\hline $\begin{array}{c}\text { Material } \\
\text { composition }\end{array}$ & $\begin{array}{c}\text { Additional carbon } \\
/ \%\end{array}$ & $\begin{array}{c}\text { Additional copper } \\
/ \%\end{array}$ \\
\hline NC100. 24 & - & - \\
\hline NC100. 24 & 0,5 & 2 \\
\hline NC100. 24 & 0,5 & 4 \\
\hline NC100. 24 & 0,5 & 8 \\
\hline NC100. 24 & 0,2 & 2 \\
\hline NC100. 24 & 0,8 & 2 \\
\hline NC100. 24 & 1 & 2 \\
\hline NC100. 24 & 1,5 & - \\
\hline $410 L$ & - & 2 \\
\hline $410 L$ & - & 4 \\
\hline $410 L$ & - & - \\
\hline Distaloy AE & - & \\
\hline
\end{tabular}

The modifications of the original material composition not only impacted the hardness and the secondary machining properties of the investigated materials but also improved the machinability with respect to energy aspects. Material composition has been altered to such a great extent that is used exclusively for experimental purposes: such great changes are actually not used in the industry.

Using the different material compositions, solid cylinders were compacted in an appropriate rigid die with a diameter of $39 \mathrm{~mm}$. The compact density of the test specimens was $6,6 \mathrm{~g} / \mathrm{cm}^{3}$ in all cases. The sintering temperature for $\mathrm{NC100.24}$ and Distaloy AE mixture was
$1120{ }^{\circ} \mathrm{C}$; and for the $410 \mathrm{~L}$ mixtures it was $1250{ }^{\circ} \mathrm{C}$. The sintering time was 30 minutes in all cases.

We measured the HV30 hardness values of the sintered test specimens with a KB Prüftechnik DKD-K hardness testing machine. Hardness values can appropriately characterize the effects of changes in original material compositions, and it can also be used to assess machinability.

It is well-known that the hardness distribution of a compacted PM specimen is not homogeneous. Because of the compacting process, the hardness of the specimen near the edges is higher than in the middle. During our measurements, we measured the average hardness values of the test specimens, the density distribution in the test specimens was not determined.

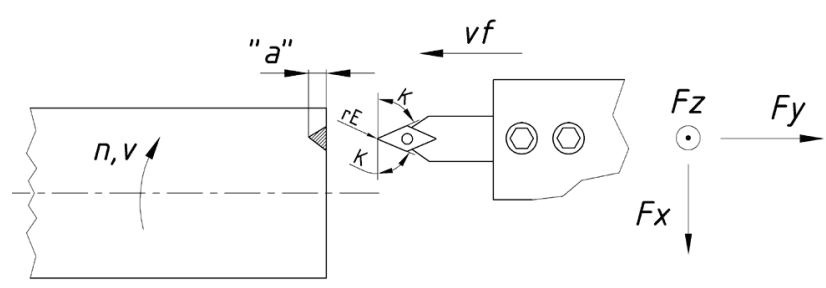

Figure 1 The measurement arrangement

In machinability experiments we used a Hembrug SLANTBED MIKROTURN $50 \mathrm{CNC}$ lathe for our investigations. A Kistler 9752A type piezoelectric dynamometer with a Kistler 5019 type amplifier was used 
for force measurements. A National Instruments 6024E DAQ Card and LabVIEW software controlled data acquisition system were used to acquire and to archive the force values during machining. The sampling frequency was set to $1000 \mathrm{~Hz}$ in all cases. The measurement arrangement can be seen in Fig. 1 .

In Fig. 1, $n, v, a$ and $v_{f}$ refer to the adjusted cutting parameters, $\kappa$ and $r \varepsilon$ refer to the parameters of the insert used, while $F z, F y$ and $F x$ refer to the measured cutting force components.

The cutting tool consisted of a Sandvik Coromant DCMT11T304-PM insert, which has TiN and Al2O3 coatings, and a Coromant SDJCR1616H11 tool holder. The insert had a $55^{\circ}$ nose angle, and $r_{\varepsilon}=0,4 \mathrm{~mm}$ nose radius. The $\kappa$ value was $95^{\circ}$.

Tab. 3 shows the cutting parameters that were used during our investigations. These parameters were kept constant in all working processes.

Table 3 The adjusted cutting parameters

\begin{tabular}{|c|c|c|}
\hline $\begin{array}{c}\text { Cutting speed } v \\
\mathrm{~m} / \mathrm{min}\end{array}$ & $\begin{array}{c}\text { Feed rate } v_{f} \\
\mathrm{~mm} / \text { revolution }\end{array}$ & $\begin{array}{c}\text { Depth of cut } \\
a / \mathrm{mm}\end{array}$ \\
\hline 150 & 0,1 & 0,5 \\
\hline
\end{tabular}

Machining a "groove" was a simple and relatively fast test method that can show the behaviour of the investigated materials. One of the machined test specimens can be seen in Fig. 2.

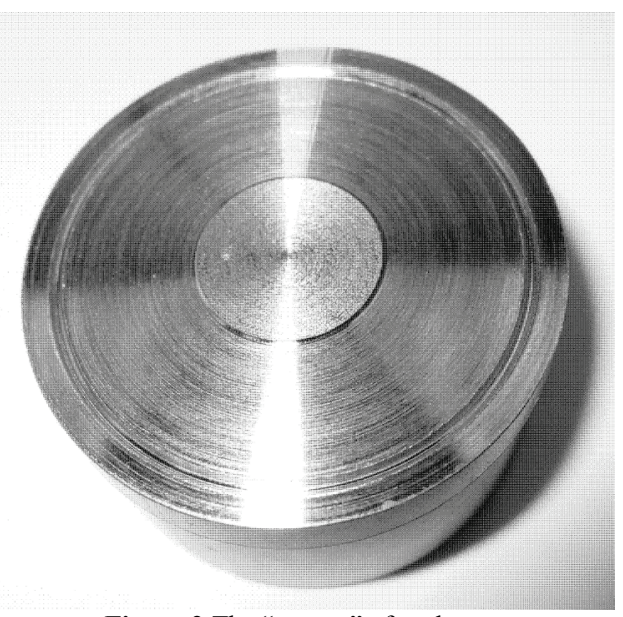

Figure 2 The "groove" after the tes

Because the grooves had a circular shape, and the depth of the grooves was only $0,5 \mathrm{~mm}$, surface roughness investigations could not be made.

Besides the above described sintered materials, conventional C45E (1.1191) steel produced by casting technologies was used as a reference material. During evaluations, measurement results were compared to the results obtained concerning this material. This way the difference between the cutting behaviour of PMS and cast steels could also be determined.

\section{Results and discussion}

The change of the original powder mixtures impacts both the production of the PM parts and their machinability. For evaluating the effects of the changed composition on the mechanical properties and on machinability of these materials a face grooving test was carried out. The validation of this test method was published in previous studies $[16,17]$. In these papers we studied the effect of the processing parameters like material composition, compact density and sintering temperature. We found that changes in material composition have an effect only on the compacting process [16]. We concluded that the relatively high carbon and moderate copper content material has a better ejecting behaviour. This is important, because if a material composition has a better ejecting behaviour, but the mechanical and machining properties are the same as those of another composition that has worse ejecting behaviour, then we should opt for the better compactable material in order to reduce the tool wear of the compacting tool.

This was followed by the study of the mechanical properties of these materials while the production parameters and material compositions of these materials were concurrently changed [17]. The tensile-strength and impact strength tests were carried out according to international standards [18]. The measurements were carried out on a TIRA test 2300 tensile-strength test machine. For that purpose, we used the tensile-strength results in the scope of this study as an evaluation specification.

In the actual grooving investigations, as mentioned above, we registered three force components: the passive force component $\left(F_{x}\right)$, the thrust force component $\left(F_{y}\right)$, and the main cutting force component $\left(F_{z}\right)$. Fig. 3 shows one example of the registered signals

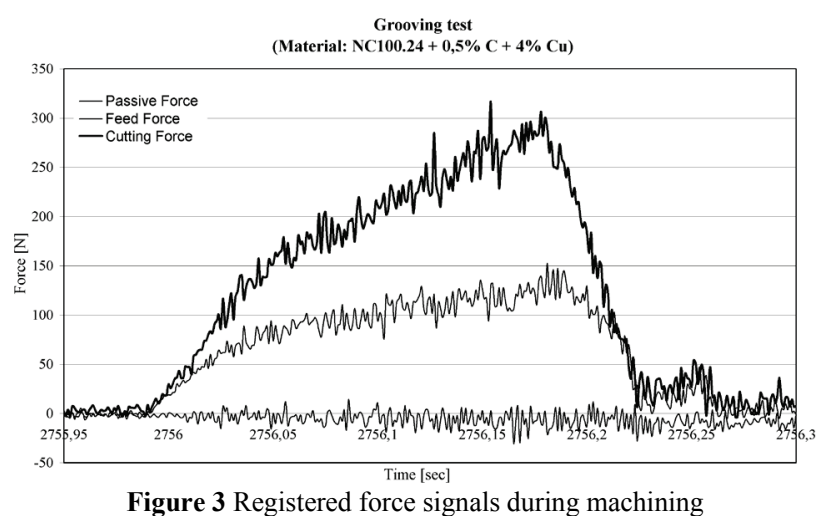

In this figure the horizontal axis shows the time elapsed during machining and the vertical axis shows the recorded cutting force components. In the case of the other materials, we got almost identical force signal shapes without any exception. The only differences between the signals were the magnitude of the cutting forces and the slope of the ramps. The passive force component did not change significantly, therefore during the evaluation this component was not considered.

After removing the transient period at the start and the finish of the grooving, we calculated the linear regression of the force components that is shown in Fig. 4.

It was also observed that the more deeply the cutting edge penetrated into the test specimen, the more the fluctuation of the cutting forces increased. The value of 
the fluctuation was different in each case, so we used that as an evaluation specification.

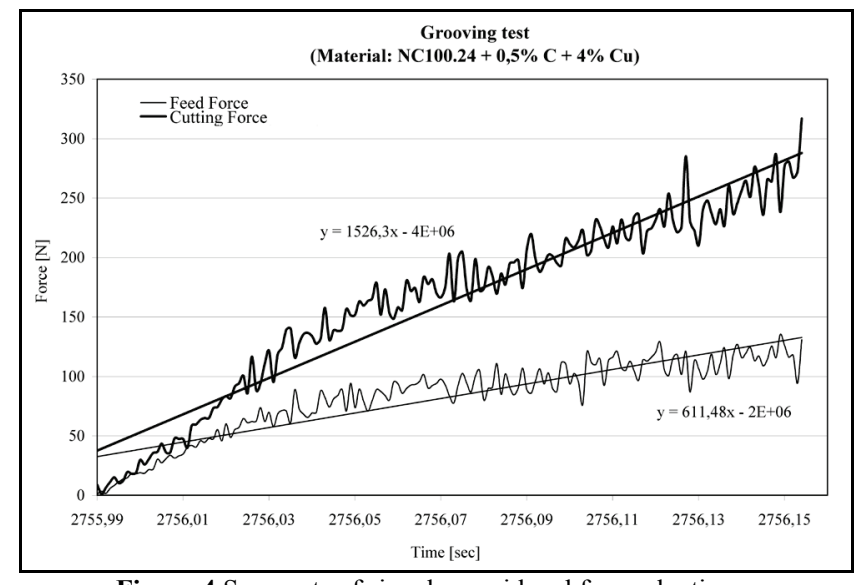

Figure 4 Segments of signals considered for evaluation

Tab. 4 shows the evaluation specifics for each PMS material after processing the registered cutting forces including HV30 hardness and tensile-strength values. In this table, $\Delta F z_{\text {max }}$ and $\Delta F y_{\text {max }}$ are the maximum values of the fluctuations in the cutting force components. These fluctuations were calculated by Eq. (1).

$$
\Delta F_{i} \max =\max \left|y_{i+1}-y_{i}\right|
$$

where $y_{i}$ and $y_{i+1}$ are the instantaneous values of the registered force components.

In each case, we fitted a linear regression curve to the considered cutting force values according to Eq. (2).

$y=b \cdot x+a+e$

where $x$ is the independent variable, $y$ is the dependent variable, $b$ is the steepness of the fitted line, a is the intercept of the fitted line and $\mathrm{e}$ is the error term.

$F_{y}$ and $F_{z}$ steepness values are the steepness values of these regression curves. For evaluation, we also used the maximum values of the force components $\left(F_{y}\right.$ and $F_{z}$ max) and the ratio of these values $\left(F_{y \max } / F_{z \max }\right)$.

The hardness and tensile-strength values of the examined PM steels can be seen in Fig. 5 .

Table 4 The evaluation specifics

\begin{tabular}{|c|c|c|c|c|c|c|c|c|c|}
\hline Material composition & $\begin{array}{c}\text { Hardness } \\
\text { HV } 30\end{array}$ & $\begin{array}{c}\text { Tensile } \\
\text { strength } \\
\mathrm{MPa}\end{array}$ & $\begin{array}{l}\Delta F_{z \max } \\
\mathrm{N}\end{array}$ & $\stackrel{\Delta F_{y \max }}{\mathrm{N}}$ & $\begin{array}{c}F_{z} \\
\text { steepness }\end{array}$ & $\begin{array}{c}F_{y} \\
\text { steepness }\end{array}$ & $F_{z \max }$ & $F_{y \max }$ & $F_{y \max } / F_{z \max }$ \\
\hline NC100.24 original & 61,9 & 196 & 59 & 53 & 1402,2 & 659,12 & 296,8 & 151,3 & 0,509 \\
\hline$+0,5 \% \mathrm{C}+2 \% \mathrm{Cu}$ & 72,6 & 309 & 72 & 37 & 1376,9 & 576,66 & 313,4 & 146,4 & 0,467 \\
\hline$+0,5 \% \mathrm{C}+4 \% \mathrm{Cu}$ & 110,5 & 322 & 48 & 27 & 1526,3 & 611,48 & 316,8 & 135,2 & 0,426 \\
\hline$+0,5 \% \mathrm{C}+8 \% \mathrm{Cu}$ & 111,3 & 352 & 82 & 92 & 1409,2 & 606 & 302,2 & 175,7 & 0,581 \\
\hline$+0,2 \% \mathrm{C}+2 \% \mathrm{Cu}$ & 80 & 278 & 49 & 36 & 1286,2 & 579,93 & 296,8 & 151,8 & 0,511 \\
\hline$+0,8 \% \mathrm{C}+2 \% \mathrm{Cu}$ & 85 & 353 & 69 & 60 & 1643,9 & 678,66 & 303,7 & 167,9 & 0,552 \\
\hline$+1 \% \mathrm{C}+2 \% \mathrm{Cu}$ & 83,4 & 337 & 113 & 79 & 1729,2 & 711,44 & 342,3 & 188,9 & 0,509 \\
\hline$+1,5 \% \mathrm{C}+2 \% \mathrm{Cu}$ & 91,5 & 298 & 73 & 81 & 1770,6 & 733,23 & 241,2 & 135,7 & 0,562 \\
\hline $410 \mathrm{~L}$ original & 125,5 & 410 & 81 & 55 & 1317,4 & 644,41 & 283,6 & 163 & 0,574 \\
\hline $410 \mathrm{~L}+2 \% \mathrm{Cu}$ & 135,5 & 432 & 71 & 31 & 1438,3 & 615,86 & 297,3 & 140,1 & 0,471 \\
\hline $410 \mathrm{~L}+4 \% \mathrm{Cu}$ & 131,5 & 444 & 40 & 40 & 1386,3 & 624,92 & 284,1 & 153,8 & 0,541 \\
\hline Distaloy AE & 206 & 395 & 221 & 110 & 2004,4 & 999,53 & 334,4 & 174,3 & 0,521 \\
\hline $\begin{array}{c}\mathrm{C} 45 \mathrm{E} \text { (reference } \\
\text { material) }\end{array}$ & 180 & 650 & 40 & 33 & 1470,64 & 726,66 & 299,8 & 168,9 & 0,563 \\
\hline
\end{tabular}

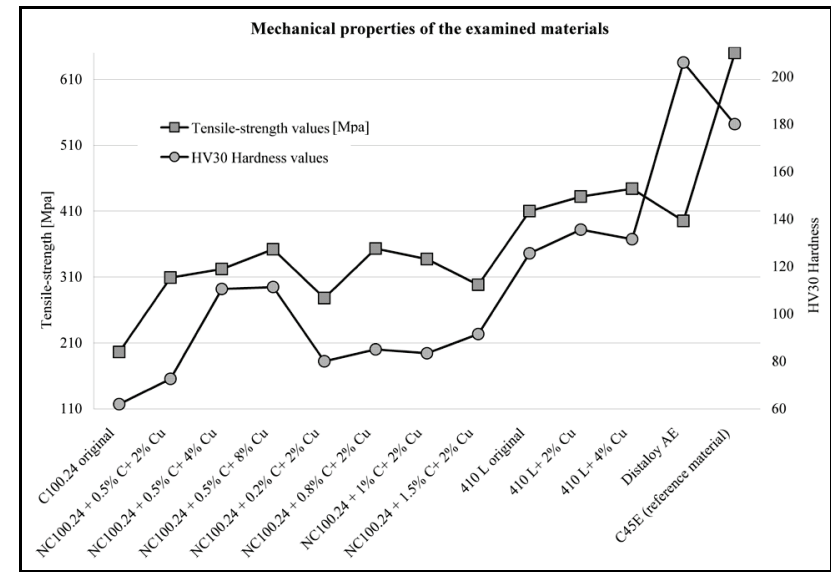

Figure 5 The HV30 and tensile-strength values of the examined PM materials

Based on the almost parallel changes of the two graphs in Fig. 5, we can conclude that the modifications of the original material compositions produce similar effects concerning changes of hardness and tensile strength values: the results clearly demonstrate that copper and carbon addition improves the hardness and tensile-strength of the materials, and that copper addition has an even greater impact. The reason for this is that copper melts at $1085^{\circ} \mathrm{C}$, in our case below the sintering temperature, and it rapidly infiltrates the pore system of a compact powder, and from here it diffuses relatively easily into the iron particles thereby improving the bonding between the particles.

As from the individual evaluation specifics we could not draw unequivocal conclusions, it was necessary to rank each specific. The hardness and tensile-strength values were not taken into account here, because they influence cutting force components. According to the absolute evaluation values in Tab. 4, each material was assigned a ranking point from 1 to 14 depending on the value of the specific. In each column in Tab. 4, the smallest value was assigned 1 point and the highest value got 14 points. These ranking points were summarized per line, as shown in Tab. 5. In Tab. 5, smaller values show better machinability. 
Fig. 6 shows the summarized ranking points of the PM steels made from the original material compositions as compared to the same values of the reference material. It is clearly shown that material Distaloy AE has the worst machinability behavior in terms of energy indicators. Compared to material NC100.24, it requires two times greater energy for machining. Thus, during further evaluations we did not take into account this material because the others have better machinability properties from our perspective. Machining the 410L stainless material is similar to machining the reference material and material NC100.24 needs the least energy for machining.

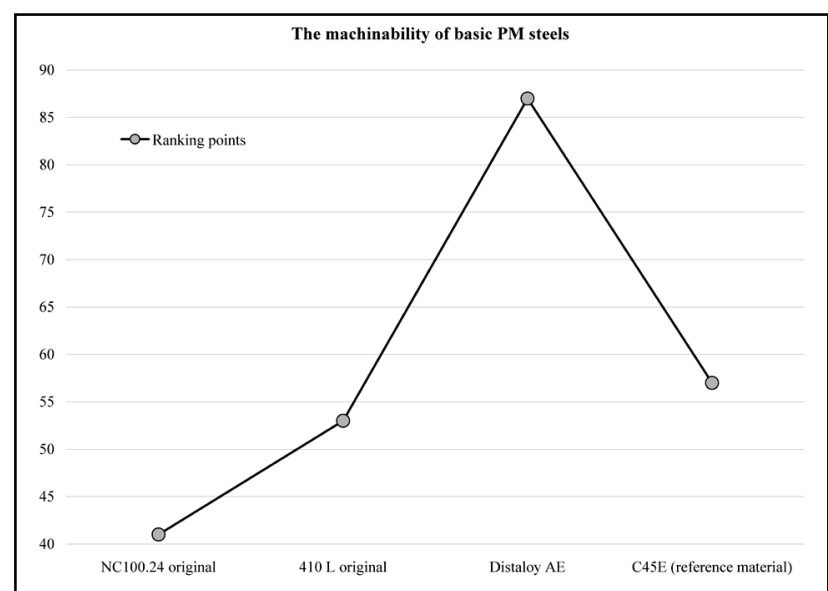

Figure 6 Basic PM steels compared to the reference material
It is obvious that the additional alloying element has an effect on machinability so we created another diagram to show the effects of the different alloying elements in the case of the different material groups. Fig. 7 shows the effect of copper addition on machinability and mechanical properties in the case of the NC100.24 material group

We can conclude that copper addition, up to a certain extent, improves machinability and mechanical properties. Above $4 \%$ of copper addition, hardness and tensile strength values did not change significantly, but the machinability of the materials deteriorated. So the optimum value of copper addition is $4 \%$ : the investigated parameters are acceptable in this case.

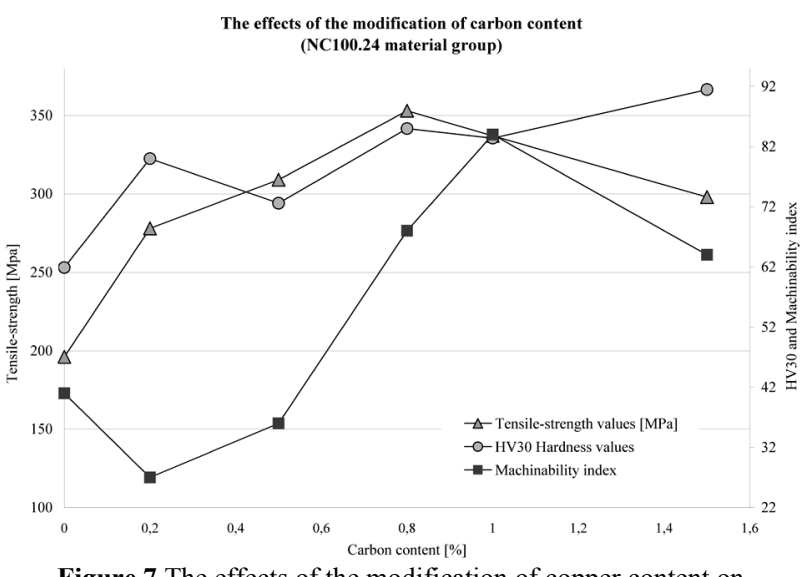

Figure 7 The effects of the modification of copper content on machinability

Table 5 The ranking points of the evaluation specifics

\begin{tabular}{|c|c|c|c|c|c|c|c|c|}
\hline Material Composition & $\begin{array}{c}\Delta F_{z \max } \\
\mathrm{N}\end{array}$ & $\begin{array}{c}\Delta F_{y \max } \\
\mathrm{N}\end{array}$ & $F_{z}$ steepness & $F_{y}$ steepness & $\begin{array}{c}F_{z \max } \\
N\end{array}$ & $\begin{array}{c}F_{y \max } \\
\mathrm{N}\end{array}$ & $F_{y \max } / F_{z \max }$ & Summa \\
\hline NC100.24 original & 7 & 6 & 9 & 4 & 5 & 5 & 5 & 41 \\
\hline$+0,5 \% \mathrm{C}+2 \% \mathrm{Cu}$ & 5 & 4 & 1 & 2 & 11 & 4 & 9 & 36 \\
\hline$+0,5 \% \mathrm{C}+4 \% \mathrm{Cu}$ & 1 & 10 & 4 & 1 & 12 & 1 & 3 & 32 \\
\hline$+0,5 \% \mathrm{C}+8 \% \mathrm{Cu}$ & 13 & 7 & 3 & 7 & 9 & 8 & 11 & 58 \\
\hline$+0,2 \% \mathrm{C}+2 \% \mathrm{Cu}$ & 4 & 1 & 2 & 5 & 5 & 6 & 4 & 27 \\
\hline$+0,8 \% \mathrm{C}+2 \% \mathrm{Cu}$ & 9 & 11 & 10 & 10 & 10 & 11 & 7 & 68 \\
\hline$+1 \% \mathrm{C}+2 \% \mathrm{Cu}$ & 11 & 12 & 11 & 9 & 14 & 14 & 13 & 84 \\
\hline$+1,5 \% \mathrm{C}+2 \% \mathrm{Cu}$ & 12 & 13 & 13 & 11 & 1 & 2 & 12 & 64 \\
\hline $410 \mathrm{~L}$ original & 8 & 3 & 7 & 13 & 3 & 9 & 10 & 53 \\
\hline $410 \mathrm{~L}+2 \% \mathrm{Cu}$ & 2 & 8 & 5 & 3 & 7 & 3 & 8 & 36 \\
\hline $410 \mathrm{~L}+4 \% \mathrm{Cu}$ & 6 & 5 & 6 & 8 & 4 & 7 & 1 & 37 \\
\hline Distaloy AE & 14 & 14 & 14 & 6 & 13 & 12 & 14 & 87 \\
\hline C45E (reference material) & 3 & 9 & 12 & 12 & 8 & 12 & 1 & 57 \\
\hline
\end{tabular}

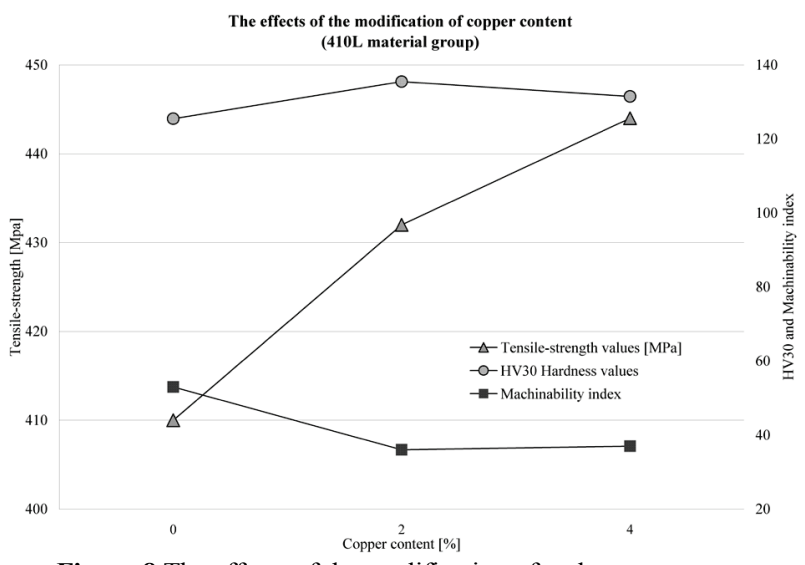

Figure 8 The effects of the modification of carbon content on machinability
Fig. 8 clearly shows that the modification of carbon content also influences the tensile-strength values and the machinability of the examined materials, but does not significantly influence hardness values.

Changes in machining and tensile-properties show a similar trend. Up to $0,2 \%$ of carbon addition, the machining properties improved, above this limit the parameters worsened. Thus, the optimum value of carbon addition is about $0,2 \%$. Normally steels with $0,2 \div 0,4 \%$ carbon contents exhibit the best machinability. Below this limit, steels tend to be smeared during machining, while above this limit the hardness of the steels is too high and significant tool wear occurs during machining. According to our results, this statement is also true for sintered metals. Fig. 9 shows the effects of the modification of copper content in the case of the $410 \mathrm{~L}$ stainless materials. 


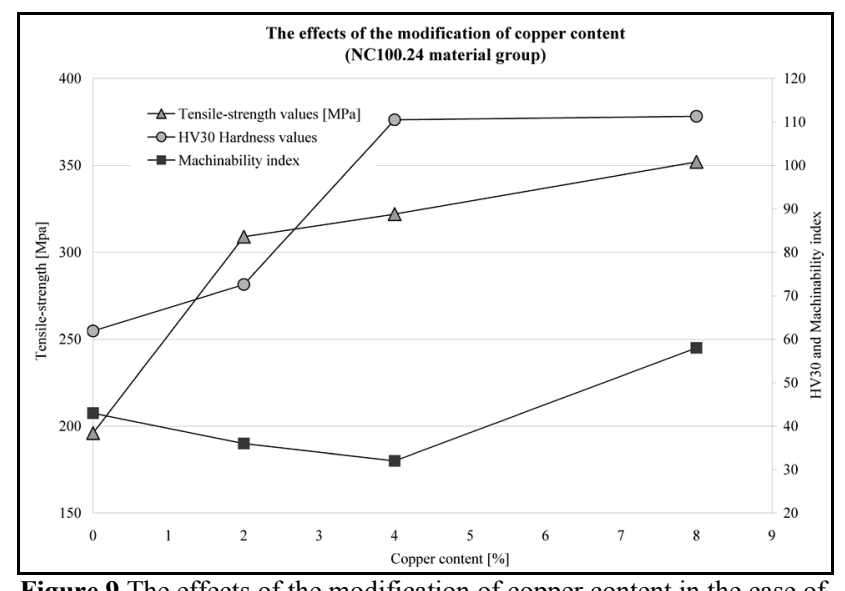

Figure 9 The effects of the modification of copper content in the case of stainless materials

This chart shows a similar trend as the one observed in the case of the NC100.24 materials: the addition of copper improves both machinability and mechanical properties. The addition of copper has a greater effect on modifications than the addition of carbon, so the addition of carbon can be replaced with copper addition in all cases in order to improve secondary machining parameters and mechanical properties.

Finally, we created diagram Fig. 10, which summarizes the machining and the mechanical properties of the examined materials sorted by machinability indexes.

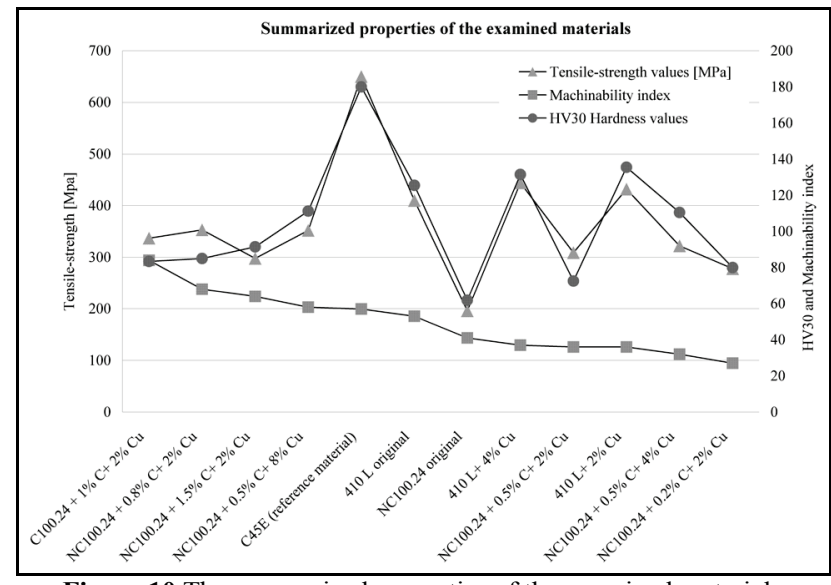

Figure 10 The summarized properties of the examined materials

Based on the data in Fig. 10, it can be claimed that it is worth to modify the original material compositions of the examined powder mixture. It is possible to reach scenarios where both mechanical and secondary machining properties improve in terms of energy indicators. As a conclusion, it can be established that material $\mathrm{NC} 100.24+0,2 \% \mathrm{C}+2 \% \mathrm{Cu}$ has the best machinability in the pure iron powder group and the same is true for the $410 \mathrm{~L}+4 \% \mathrm{Cu}$ material in the stainless powder group.

It has also been established that the original powder mixtures have the same behaviour as the reference material and any addition of alloying alters this behaviour either in the wrong or the right direction. It is interesting to note that during the machining of high copper-content material NC100.24 low cutting forces, moderate tool wear, but strong vibrations were realized. In contrast to this, during the machining of material Distaloy $+0,5 \% \mathrm{C}$, high cutting forces, significant tool wear and weak vibrations were observed, just like in the case of high carbon content sintered materials. Besides, it has also been shown how difficult it is to clearly rank the machinability of powder metallurgy steels.

\section{Conclusion}

In the scope of this study, we investigated the machinability properties of powder metallurgy steels with different material compositions in terms of energy indicators. The tests were performed on a high precision $\mathrm{CNC}$ lathe using simple grooving operations and cutting force measurements. The main results of our investigation are the following:

- A new test method, called the "grooving test" and a ranking evaluation method were used to evaluate the secondary machining properties of the investigated MMCs.

- According to our goals we could improve the secondary machining properties of the examined materials increasing the percentage of the ordinary alloying elements in the base powder mixtures.

- It can be concluded that the addition of copper increases the mechanical properties of the materials and improves machinability up to $4 \%$. Above this limit, the machinability properties deteriorate and the mechanical properties did not improved significantly. The same effect can be observed in the case of stainless powder metallurgy parts. Hence, we can conclude that the optimal value of the copper addition is $4 \%$ in the case of the NC100.24 materials.

- Over $1 \%$ addition of carbon decreases machinability but improves the hardness of sintered metals. However, until up to $0,2 \%$ carbon content also helps to machine these materials. The effect of the carbon content modification influences machinability to a lesser extent. Therefore, in order to improve the secondary machining properties of the PMS materials increased copper content should be preferred in contrast with increased carbon composition.

- The results of the grooving test proved that PMS materials made of original material compositions exhibit a similar cutting behaviour than the reference steel C45E. Materials with $4 \%$ copper and 0,2\% carbon addition have the best machinability and the use of increased amounts of alloying elements decreases machinability.

- The copper addition had the same effect on mechanical and machinability properties in the stainless powder mixture group like in the pure iron powder mixture group.

- Copper addition should be preferred against carbon addition where it is possible in order to produce parts with better mechanical properties.

\section{Acknowledgements}

This research is partly supported by the Hungarian Scientific Research Fund under project number OTKA 101703. The research results are used in the international bilateral project "Multi-sensors based intelligent tool 
condition monitoring in mechanical micro-machining" listed under number TÉT 10-1-2011-0233. The authors would also like to acknowledge the support provided by the CEEPUS III HR 0108 project. The authors also express their gratitude to Carbosint $\mathrm{Kft}$. for supporting the production of test specimens and for cooperating in their evaluation.

\section{$5 \quad$ References}

[1] Högänas Handbook for Sintered Components. 2006. URL: http://hoganas.com/Documents/Handbooks/Book\%202\%20 Production $\% 20$ of $\% 20$ Sintered $\% 20$ Components $\% 20$ Dec\%2 02013.pdf,(10.11.2014.).

[2] Chmielewski, M.; Nosewicz, S.; Pietrzak, K.; Rojek, J.; Strojny-Nędza, A.; Mackiewicz, A.; Dutkiewicz, J. Sintering Behavior and Mechanical Properties of NiAl, $\mathrm{Al2O} 3$, and NiAl-Al2O3 Composites. // Journal of Materials Engineering and Performance. 23, 11(2014), pp. 3875-3886. DOI: 10.1007/s11665-014-1189-z

[3] Isik, Y. Investigating the Machinability of Tool Steels in Turning Operations. // Materials and Design. 28 (2007), pp. 1417-1424. DOI: 10.1016/j.matdes.2006.03.025

[4] Wang, F.; Zhao, J.; Li, A.; Zhao, J. Experimental Study on Cutting Forces and Surface Integrity in High-Speed Side Milling of Ti-6Al-4V Titanium Alloy. // Machining Science and Technology. 18, 3(2014), pp. 448-463. DOI: 10.1080/10910344.2014.926690

[5] Krolczyk, G.; Legutko, S.; Nieslony, P.; Gajek, M. Study of the surface integrity microhardness of austenitic stainless steel after turning. // Tehnicki vjesnik-Technical Gazette. 21, 6(2014), pp. 1307-1311

[6] Hricova, J.; Kovac, M.; Sugar, P. Experimental investigation of high speed milling of aluminium alloy. // Tehnicki vjesnik-Technical Gazette. 21, 4(2014), pp. 773777.

[7] Capus, J. A New PM Route for Machinable, Malleable Iron. // Metal Powder Report. 67, 5(2012), pp. 30-32. DOI: 10.1016/S0026-0657(12)70078-4

[8] Capus, J. Forward Progress in the Machining of PM Steel Parts. // Metal Powder Report. 68, 5(2013), pp. 22-24. DOI: 10.1016/S0026-0657(13)70170-X

[9] Narayanasamy, R.; Anandakrishnan, V.; Pandey, K. S. Effect of Carbon Content on Workability of Powder Metallurgy Steels. // Materials Science and Engineering. 494, 1-2(2008), pp. 337-342.

[10] Narayanasamy, R.; Anandakrishnan, V.; Pandey, K. S. Effect of Molybdenum Addition on Workability of Powder Metallurgy Steels during Cold Upsetting. // Materials Science and Engineering. 517, 1-2(2009), pp. 30-36.

[11] Sortino, M.; Totis, G.; Prosperi, F. Dry Turning of Sintered Molybdenum. // Journal of Materials Processing Technology, 213, 7(2013), pp. 1179-1190. DOl: 10.1016/j.jmatprotec.2013.01.017

[12] Suhasini, G.; Mamidala, R.; Pedersen, W. Machining of MMCs: A Review. // Machining Science and Technology, 17, 1(2013), pp. 41-73. DOI: 10.1080/10910344.2012.747897

[13] Stojanović, B.; Ivanović, L. Application of Aluminium Hybrid Composites in Automotive Industry. // Tehnicki vjesnik-Technical Gazette. 22, 1(2015), pp. 247-251. DOI: 10.17559/TV-20130905094303

[14] Bo, H.; Warzel, R. T. The Use of a New Machinability Enhancer for Improving the Machinability of Pre-alloyed Powder Metal Components Without Detrimental Effects on the Material Characteristics. 2010. URL: http://www.hoganas.com/Documents/Published\%20Article s/2010/Powdermet2010_PM10_03_Hu_Warzel_The_use_o f a new Machinability_enhancer2.pdf, (10.11.2014.).
[15] Bo, H.; Warzel, R. T. Machinability Enhancement of PM Stainless Steels Using Easy-Machinable Stainless Steel Powder. 2013. URL: http://www.hoganas.com/Documents/ Published\%20Articles/2013/PM13 03 PowderMet2013 M achinability_Enhancement_of_PM_Stainless_Steel_Bo_Hu .pdf, (10.11.2014).

[16] Czampa, M.; Zatykó, S.; Németh, Á.; Szalay, T. Change of Physical and Geometrical Characteristics of Sintered Iron Components Due to Varying the Process Parameters. // Proceedings of the IN-TECH 2011 / Bratislava, 2011, pp. 95-99.

[17] Czampa, M.; Németh, Á.; Zatykó, S.; Szalay, T. Improvement of the Mechanical Properties of Sintered Metals by Modifying the Process Parameters. // Proceedings of the APMAS 2012 / Antalya, 2012, pp. 208211. DOI: $10.1063 / 1.4751596$

[18] ISO 2740:2010. Sintered Metal Materials, Excluding Hardmetals. Tensile Test Pieces. // International Organization for Standardization.

[19] Czampa, M.; Markos, S.; Farkas, B. Zs.; Szalay, T. Machinability of Sintered Metals. // Proceedings of the ICT 2012 / Miskolc, 2012, pp. 139-14.

[20] Bo, H.; Warzel, R. T. The Use of a New Machinability Enhancer for Improving the Machinability of Pre-alloyed Powder Metal Components Without Detrimental Effects on the Material Characteristics. 2010. URL: http://www.hoganas.com/Documents/Published\%20Article s/2010/Powdermet2010 PM10 03 Hu Warzel The use o f a new Machinability enhancer2.pdf, (10.11.2014.).

[21] Bo, H., Warzel, R. T. Machinability Enhancement of PM Stainless Steels Using Easy-Machinable Stainless Steel Powder. 2013. URL:http://www.hoganas.com/Documents/ Published\%20Articles/2013/PM13_03_PowderMet2013_M achinability_Enhancement_of_PM_Stainless_Steel_Bo_Hu .pdf, (10.11.2014).

[22] Czampa, M.; Zatykó, S.; Németh, Á.; Szalay, T. Change of Physical and Geometrical Characteristics of Sintered Iron Components Due to Varying the Process Parameters. // Proceedings of the IN-TECH 2011 / Bratislava, 2011, pp. 95-99.

[23] Czampa, M.; Németh, Á.; Zatykó, S.; Szalay, T. Improvement of the Mechanical Properties of Sintered Metals by Modifying the Process Parameters. // Proceedings of the APMAS 2012 / Antalya, 2012, pp. 208211. DOI: $10.1063 / 1.4751596$

\section{Symbols and abbreviations}

$n \quad$ - revolution of the main spindle in $1 / \mathrm{min}$

$v \quad$ - cutting speed in $\mathrm{m} / \mathrm{min}$

a $\quad$ - depth of cut in mm

$v_{f} \quad$ - feed rate in $\mathrm{mm} / \mathrm{rev}$

$\kappa \quad$ - clearance angle of the insert in ${ }^{\circ}$

$r_{\varepsilon} \quad$ - the nose radius of the insert in $\mathrm{mm}$

$F_{z} \quad$ - Main cutting force component in N

$F_{y} \quad$ - Feed cutting force component in N

$F_{x} \quad$ - Passive cutting force component in N

MMC - Metal Matrix Composites 


\section{Authors' addresses}

Miklós Czampa, Assistant lecturer

Budapest University of Technology and Economics,

Department of Manufacturing Science and Engineering

Müegyetem rkp. 3, H-1111 Budapest, Hungary

E-mail: czampa@manuf.bme.hu

\section{Balázs Zsolt Farkas, Assistant lecturer}

Budapest University of Technology and Economics,

Department of Manufacturing Science and Engineering

Mủegyetem rkp. 3, H-1111 Budapest, Hungary

E-mail: farkasb@manuf.bme.hu

Tibor Szalay, Dr., Associate professor, Head of Department

Budapest University of Technology and Economics,

Department of Manufacturing Sciences and Engineering

Mủegyetem rkp. 3, H-1111 Budapest, Hungary

E-mail: szalay@manuf.bme.hu 